\title{
The Hedonic Pricing Model Applied to the Housing Market of the City of Savannah and Its Savannah Historic Landmark District
}

\author{
Richard J. Cebula*
}

\begin{abstract}
This study applies a hedonic pricing model to the housing market of the City of Savannah, Georgia. The Savannah Historic Landmark District is located both in and adjacent to downtown Savannah. Of the 2,888 single-family homes for the period 20002005 for which data are available, 591 are located in the Historic District. The model of the real sales price of a single-family house in the City of Savannah environment reveals it is positively affected by the number of bathrooms, fireplaces, bedrooms, stories in structure, garage car spaces, square feet of finished living space, the presence of a deck, a private courtyard, a pool and/or hot-tub, an exterior construction of brick or stucco, the presence of an underground sprinkler system, and whether the house was new. Six spatial control variables are considered. Locations across from, or adjacent to, open space carry premia, as do locations on cul-de-sacs or lakes. Corner properties do not. In addition, proximity to an apartment complex is capitalized as a negative quantity, as do locations on a busy street. The real sales price of residential properties that closed during May or July tend to be higher. In addition, houses designated as a national historical monument tend to carry with them a modest price premium, as do properties that are simply located within the Savannah Historic Landmark District.
\end{abstract}

Key Words: Housing prices; Hedonic model; City of Savannah

JEL Classifications: R14; R13; R11

\section{INTRODUCTION}

Hedonic pricing models (c.f. surveys by Boyle and Kiel, 2001, and Sirmans, Macpherson, and Zeitz, 2005) have been used to assess the impacts of historic district designation on property values (Coffin, 1989; Ford, 1989; Asabere and Huffman, 1994; Asabere, Huffman and Mehdian, 1994; Clark and Herrin, 1997; Coulson and Leichenko, 2001; Leichenko, Coulson, and Listokin, 2001; Coulson and Lahr, 2005) among many other circumstances. The present study seeks to some extent to extend this literature by applying the approach to the prices of single-family properties in the City of Savannah, Georgia. The Savannah Historic Landmark District is located both in and adjacent to downtown Savannah. Although housing prices in the present study's geographic area received cursory attention some 30 years ago (U.S. Advisory Panel on Historic Preservation, 1979), they have not yet been subjected to rigorous investigation. ${ }^{1}$ Sales of singlefamily properties per se within the City of Savannah for which adequate data were available for

\footnotetext{
*Richard J. Cebula is the Walker/Wachovia Professor of Finance, Economics and Finance Department, Jacksonville University, Jacksonville, FL 32211; E-mail: Dr.RichardCebula@gmail.com

${ }^{1}$ The geography of interest, the downtown area of the Savannah, Georgia, metropolitan area, is nationally regarded as an architectural gem. The Historic Savannah Foundation, established in the mid-1950s with the goal of preserving buildings of architectural merit in the city, has estimated that nearly 40 percent of the city's buildings are of architectural or historical significance. Accordingly, the downtown historic district was designated as a National Historic Landmark District in 1966. In 1968, an act of the Georgia State Legislature authorized specific zoning regulations that apply within the historic landmark district. An institutional framework within which building demolition, renovation, preservation, and construction would be evaluated for consistency with the guidelines governing development in the historic landmark district was established in 1973 and remains operational today
}

(C) Southern Regional Science Association 2010.

ISSN 1553-0892

SRSA, 1601 University Avenue, PO Box 6025, Morgantown, West Virginia 26506-6025, USA. 
the study period 2000-2005 are included in this study. In total, the analysis includes 591 singlefamily home sales from the Savannah Historic Landmark District per se, and 2,297 single-family home sales from the City of Savannah outside the Historic District. The relatively large volume of home sales data available from the Historic District vis-à-vis that available for most previous studies undoubtedly reflects the Savannah Historic Landmark District's distinction as the single largest historic district containing single-family properties in the United States.

In a broader context, aside from being the first study to apply the hedonic pricing model to the Savannah Historic Landmark District and to do so within the broader context of the city of Savannah housing market, this study differs from prior hedonic pricing models of historic district property transactions in other ways. First and possibly foremost, this study makes use of a substantially larger data set of property transactions for a historic district. For comparison, 591 actual single-family home sales for a historic district are used, whereas between 15 and 62 actual house sales in historic districts are used as elements of larger data sets in the works of Coffin (1989), Asabere and Huffman (1994), Clark and Herrin (1997) and Leichenko, Coulson, and Listokin (2001). The latter study also analyzes additional data for up to 2,200 historic district houses drawn from municipal appraisal records in Texas. However, as such, the housing values considered are not based on actual market transactions and are subject to the well-known inconsistencies inherent in nonmarket valuation techniques (Coulson and Lahr, 2005), despite claims of city appraisers to the contrary (Leichenko, Coulson, and Listokin, 2001). In the present study, by contrast, all 2,888 housing prices are the result of actual market transactions.

Another interesting aspect of the present study is the application of variables that capture the seasonal variation of house sales prices in a historic district and the surrounding city within the hedonic pricing model - the variables MAY, JUNE, and JULY. This specification allows us to expressly model a recurring pattern in monthly data that is not accounted for in most previous research on residential property prices, let alone those on historic districts. In addition, the study integrates a variable (HISTDES) to reflect whether a property sale included a structure that has been officially designated as a national historic landmark. As well, it would seem appropriate to distinguish between property sales within the Savannah Historic Landmark District on the one hand, and other property sales outside the "District" but within the City of Savannah, on the other hand. This is because there may be a premium applied to sales of the former variety (Sirmans, Macpherson, and Zeitz, 2005). Therefore, a dummy variable (DISTRICT) is introduced. The sign, magnitude and statistical significance of the estimated coefficient on DISTRICT allows us to infer the extent to which location within the Savannah Historic Landmark District is capitalized into the values of properties in the City of Savannah. Next, as in a number of other related studies, spatial control variables are included in the model; six are considered in the present study. It is also appropriate to note that each property sales price investigated over the six-year period from 2000 to 2005 has been adjusted using an index of housing prices per se over the study period. The result is that each and every housing price observation is expressed in 2005 dollars, i.e., in arguably appropriate, comparable terms. The use of a housing price index rather than the national or a regional consumer price index, which is the method employed in much of the existing hedonic literature on historic districts, is justified because a broadly based CPI, by definition, incorporates the prices of effectively all household consumption goods and services, most of which are entirely unrelated to the prices per se of single-family homes. 
In the next section of this paper, the hedonic pricing model is detailed, and the data are described. Following conventional practice in the literature, the model is estimated in semi-log form. The empirical estimates of three model specifications are summarized in the subsequent section of the study. In addition, the overall empirical results are interpreted. The conclusion provides a summary of the results, as well as an extension of the model.

\section{THE FRAMEWORK FOR THE EMPIRICAL ANALYSIS}

This section of the study provides the framework within which the hedonic pricing model is applied to housing sales in the Savannah Historic Landmark District and the City of Savannah of which it is a part. The underlying theory and a summary of empirical results of applied hedonic pricing models are thoroughly described in, for example, Sirmans, Macpherson, and Zeitz (2005), so they are not detailed here. The basic premise is that a property represents a bundle of both desirable and undesirable attributes to utility-maximizing consumers, all of which contribute to the market value of the house as revealed through a market transaction, i.e., a property sale. The hedonic pricing model decomposes the transaction price into various components such as interior and exterior features, and other traits of the house that affect the sales price. The estimated parameters of the model provide information about the relative contribution (significance and magnitude of effect) of any given house feature.

In the present study, the hedonic pricing model takes the following general form:

$$
\ln \left(R S A L E S P R_{j}\right)=f\left(I_{j}, E_{j}, S C_{j}, O_{j}\right)
$$

where:

$\ln \left(R S A L E S P R_{j}\right)=$ the natural log of the real price of house $j$ in 2005 dollars;

$I_{j}=$ a vector of interior physical characteristics for house $j$;

$E_{j}=$ a vector of external physical characteristics for house $j$;

$S C_{j}=$ a vector of spatial control variables for house $j$; and

$O_{j}=$ a vector of other factors associated with house $j$.

The present study applies the hedonic model to home sales in the Savannah Historic Landmark District and the city of Savannah, of which it is a component, over the six-year period from 2000 through 2005. Data for 2,888 home sales for which there was sufficient information for analysis during this time frame in the city of Savannah (591 of which were in the Savannah Historic Landmark District) were obtained from the Savannah Board of Realtors' Multiple Listing Service (MLS). A modest number of homes (139) were omitted because of a lack of needed data. Unlike the City of Savannah as a whole, where 839 property home sales (29 percent of all single-family residential property sales) involved new homes, the vast majority of the 591 observations for the Savannah Historic Landmark District represent resales of existing homes: only 40 Historic District sales (6.7 percent) were newly built structures. In order to permit comparison of sales prices across the study period, all property prices were converted to and expressed in 2005 dollars using the price index for single-family homes from the U.S. Census Bureau (2007, Table 710). The mean price of a property sold in the Savannah Historic Landmark District from 2000 to 2005, expressed in 2005 dollars, was \$346,250.50, as compared to the corresponding mean price of $\$ 239,281.16$ for the studied sample for the City of Savannah as a whole.

(c) Southern Regional Science Association 2010. 
TABLE 1. Definitions of the Variables in the Analysis: Savannah, Georgia, U.S.A.

RSALESPR= property price expressed in 2005 dollars

$B A T H S=$ the total number of baths (full plus half)

FIREPLACES= the number of fireplaces

$B E D R O O M S=$ the total number of bedrooms

$S Q F T=$ the total number of square feet of finished living space

$B R I C K=$ a binary variable indicating whether a primary structure had a primarily or completely brick exterior (= 1 if yes, $=0$ otherwise)

$D E C K=$ a binary variable indicating whether the property had an exterior deck ( $=1$ if yes, $=0$ otherwise)

$C R T Y D=$ a binary variable indicating whether the property had a private courtyard $(=1$ if yes, $=0$ otherwise)

SPRINKLER= a binary variable indicating whether the property had an underground sprinkler system ( $=1$ if yes, $=0$ otherwise)

STORIES = the number of stories/floors in the structure

$S T U C C O=$ a binary variable indicating whether the structure had a stucco exterior (=1 if yes, $=0$ otherwise)

$G A R A G E S P=$ the number of garages spaces

$P O O L T U B=$ a binary variable indicating whether house $\mathrm{j}$ had its own hot-tub and/or swimming pool ( $=1$ if yes, $=0$ otherwise)

$N E W=$ a binary variable indicating whether the structure was new at the time of sale (=1 if yes, = 0 otherwise)

$P A R K S Q=$ a binary variable indicating whether the property was located across from or adjacent to a park or square, i.e., a small park ( $=1$ if yes, $=0$ otherwise)

$C O R N E R=$ a binary variable to indicate whether the property was located on a corner ( $=1$ if yes, $=0$ otherwise)

$C U L=$ a binary variable to indicate whether the property was located on a cul-de-sac (=1 if yes, $=0$ otherwise)

$L A K E R I V=$ a binary variable to indicate whether the property was located on a lake or river $(=1$ if yes, $=0$ otherwise)

APCOMP = a binary variable to indicate whether the property was located within two blocks of an apartment complex exceeding four rental units ( $=1$ of yes, $=0$ otherwise)

BUSYST = a binary variable to indicate whether the property was located on one of Savannah's busy streets_-namely, Abercorn Street, De Renne Avenue, Montgomery Cross, Habersham, White Bluff/Coffee Bluff, or Oglethorpe ( $=1$ if yes, $=0$ otherwise)

$M A Y=$ a binary variable to indicate month of closing (=1 for May, $=0$ otherwise)

$J U N E=$ a binary variable to indicate month of closing ( $=1$ for June, $=0$ otherwise)

$J U L Y=$ a binary variable to indicate month of closing (= 1 for July, $=0$ otherwise)

HISTDES = a binary variable indicating whether structure was designated as a National Historic Landmark ( $=1$ if yes, $=0$ otherwise)

DISTRICT = a binary variable indicating whether the property was located in the Savannah Historic Landmark District (= 1 if yes, = 0 otherwise) 
TABLE 2: Descriptive Statistics of Study Variables

\begin{tabular}{lrr}
\hline \hline Variable & Mean & $\begin{array}{r}\text { Standard } \\
\text { Deviation }\end{array}$ \\
$\ln ($ RSALESPR $)$ & 11.800 & 0.894 \\
BATHS & 2.253 & 1.812 \\
FIREPLACES & 1.090 & 1.300 \\
BEDROOMS & 2.600 & 1.626 \\
SQFT & 1,789 & 1,280 \\
ln(SQFT) & 7.230 & 0.610 \\
BRICK & 0.191 & 0.469 \\
DECK & 0.059 & 0.250 \\
CRTYD & 0.064 & 0.152 \\
SPRINKLER & 0.018 & 0.229 \\
STORIES & 1.811 & 0.982 \\
STUCCO & 0.181 & 0.288 \\
GARAGESP & 0.196 & 0.333 \\
POOLTUB & 0.015 & 0.161 \\
NEW & 0.286 & 0.299 \\
PARKSQ & 0.059 & 0.209 \\
CORNER & 0.052 & 0.356 \\
CUL & 0.012 & 0.031 \\
LAKE & 0.009 & 0.011 \\
APCOMP & 0.099 & 0.065 \\
BUSYST & 0.011 & 0.008 \\
MAY & 0.120 & 0.271 \\
JUNE & 0.081 & 0.292 \\
JULY & 0.111 & 0.272 \\
HISTDES & 0.012 & 0.022 \\
DISTRICT & 0.205 & 0.296 \\
\hline
\end{tabular}

There were a variety of interior and exterior physical characteristics available in the MLS data for each property sold, as well as other factors, namely, spatial factors such as location near a park or square, on a cu-de-sac, on a river or lake, near a busy street, and near an apartment complex that were available and expressly included in the analysis. These factors are listed and formally defined in Table 1 . The interior physical characteristics investigated include BATHS, the total listed number of baths (full plus half baths); FIREPLACES, the total number of listed fireplaces; BEDROOMS, the total number of listed bedrooms; and SQFT, the total listed number of square feet of finished interior living space. Basic descriptive statistics for each of the variables considered in the analysis are provided in Table 2. Naturally, for each of the impacts of 
the explanatory variables on housing price in the model, the expected sign is proffered under the assumption of ceteris paribus.

As observed in Sirmans, Macpherson, and Zeitz (2005), and based on a variety of other studies, including Ford (1989), Clark and Herrin (1997), Coulson and Leichenko (2001), Leichenko, Coulson, and Listokin (2001), Laurice and Bhattacharya (2005), Decker, Nielsen and Sindt (2005), and Coulson and Lahr (2005) the real sales price (RSALESPR) of house $j$ is expected to be an increasing function of the number of desirable internal physical housing characteristics. For example, RSALESPR is expected increase with the number of bathrooms and fireplaces. It also is expected to be an increase with the number of bedrooms and the square footage of finished living space.

The exterior physical characteristics applied include BRICK, whether the exterior is made principally of brick; DECK, whether the house has a deck; CRTYD, whether the house has a private courtyard; SPRINKLER, whether the house has an underground sprinkler system; STORIES, the number of stories in the house structure; STUCCO, whether the house exterior is of stucco construction; GARAGESP, the number of garage car spaces that are part of the house; and POOLTUB, whether the house has a hot-tub and/or a swimming pool. Lot size is not considered as a separate variable in this study. This is because lot size is not always given in the Savannah MLS for properties in the Historic District. This may well be because most properties in the Savannah Historic Landmark District, after including a private courtyard and/or a pool/hot-tub, have footprints that de facto cover the entirety of the lot. In other words, in many cases, the very small lot size is already effectively reflected in other variables in the analysis, especially SQFT, CRTYD, and POOLTUB.

As observed in Sirmans, Macpherson, and Zeitz (2005), Leichenko, Coulson, and Listokin (2001), Clark and Herrin (1997), Coulson and Lahr (2005), and elsewhere, the property prices in cities tend to increase with the number of stories structures have and when homes' exteriors are brick. As Sirmans, Macpherson, and Zeitz (2005) also observe, property prices are expected to increase with the presence of a deck, a pool, or hot-tub (Laurice and Bhattacharya, 2005) and with the number of garage spaces (Leichenko, Coulson, and Listokin, 2001; Laurice and Bhattacharya, 2005). Stucco exteriors (rather than one of clapboard or vinyl siding) should tend to enhance property prices. Finally, we hypothesize that private courtyards should enhance the prices of single-family properties, as should operating underground sprinkler systems (Sirmans, Macpherson, and Zeitz, 2005).

Newer homes (NEW) should also yield a property price premium. As suggested in Sirmans, Macpherson and Zeitz (2005), Clark and Herrin (1997), Decker, Nielsen, and Sindt (2005), Ford (1989), Laurice and Bhattacharya (2005), and Coulson and Lahr (2005), a new house is often more desirable, in part because it is in need of little or no repair and is generally cleaner and brighter and equipped with new and modern appliances; hence, a new house per se is expected to command a higher sales price. Insofar as the Savannah Historic Landmark District is concerned, this argument is consistent with Coulson and Lahr (2005, p. 506) who find that “...new properties benefit...from being within a historic district.” Accordingly, it is argued here that a new house should tend to command a greater market price.

Six spatial control variables are included in the model; counterparts to most of these are found in one or another of the studies included in the related literature (Sirmans, Macpherson, and Zeitz, 2005). To begin, it is hypothesized that properties located across from or adjacent to a 
park or square (PARKSQ) or properties located on a corner (CORNER) may be more appealing and, hence, command higher prices. Similarly, properties on cul-de-sacs (CUL) or on a lake or river (LAKERIV) should also command higher prices. On the other hand, properties located within two blocks of an apartment complex (APCOMP), defined as a rental-only complex consisting of more than four rental units, or on one of Savannah's busy streets (BUSYST) namely Abercorn Street, De Renne Avenue, Montgomery Cross, Habersham Street, White Bluff Avenue/Coffee Bluff Road, or Oglethorpe Avenue-should command a lower price because of the noise and other pollution associated with the higher vehicular and pedestrian congestion that define them as busy streets.

In addition, there is the residual category of "other factors" considered in this study. To begin, it is argued here, given the historical culture of Savannah, that if a single-family house has received designation as a national historic landmark (HISTDES), it should command a higher market price to reflect an element of "prestige" or "distinction." Then there is the separate issue of location in the Savannah Historic Landmark District per se. If a house in the City of Savannah is located in the District (HISTDIST), it is hypothesized that its market value is greater as a result of the element of prestige associated with this location. Not surprisingly, about 90 percent of Savannah's landmark single-family homes are found within the District. Finally, sales data for the city clearly indicate that a abnormally large share of property closings in this market occur during the three consecutive months of May, June, and July. That is, more properties go on sale during this period and more buyers shop for them as well. Hence, it is not clear whether there should be any seasonal effect on market prices. Moreover we found no literature that discusses whether properties sold during peak market periods should be hypothesized to be higher or lower. Ergo, to control for this phenomenon, dummy variables for MAY, JUNE, and JULY are included in the study.

\section{EMPIRICAL RESULTS}

This section provides the results of empirically estimating the hedonic model outlined above. In all of the estimates, White's (1980) procedure is adopted to correct for heteroskedasticity. Three estimates are provided: the original model and two variations thereof. In Model (a) in Table 3, 24 estimated coefficients are provided, with 15 being statistically significant at the one percent level and 7 more statistically significant between the five and one percent levels. The coefficient of determination (0.86) indicates that the model explains a very reasonable share of the variation in the dependent variable. Finally, the $F$-value is significant at far beyond the one percent level, evidence of the overall strength of the model.

Based on Model (a) in Table 3, the real sales price (expressed in natural log form) of single-family houses in the City of Savannah is a positive function of the number of bathrooms, fireplaces, bedrooms, garage spaces, stories in structure, and the number of square feet of finished living space in the house. In addition, the presence of a pool or hot-tub, a deck, a private courtyard, or an underground sprinkling system adds to the sales price. An exterior construction of brick or stucco, and a new structure also tend to increase the sales price of the property. Location across from or adjacent to a park or square also appears to enhance sales price, although corner location does not appear to be an influence. Location on a cul-de-sac or either a lake or river tend to enhance property prices significantly, whereas proximity to either an apartment complex or a busy street reduces them. Designation as a national historic landmark is apparently appealing and enhances property prices. Furthermore, the coefficient on HISTDIST 
TABLE 3. OLS Estimates of the Hedonic Pricing Model for the Dependent Variable Natural Log of Property Sales Price

\begin{tabular}{lrrr}
\hline \hline Variable & Model (a) & Model (b) & Model (c) \\
\hline Constant & 11.92 & 11.27 & 9.01 \\
BATHS & 0.104 & 0.105 & 0.104 \\
& $(3.39)$ & $(3.33)$ & $(3.35)$ \\
FIREPLACES & 0.06 & 0.061 & 0.059 \\
& $(4.18)$ & $(4.10)$ & $(3.95)$ \\
BEDROOMS & 0.083 & 0.084 & 0.089 \\
& $(2.80)$ & $(2.85)$ & $(3.20)$ \\
SQFT & 0.00016 & 0.00017 & - \\
& $(2.63)$ & $(2.64)$ & - \\
In(SQFT) & - & - & 0.482 \\
& - & - & $(4.15)$ \\
BRICK & 0.21 & 0.211 & 0.201 \\
& $(3.62)$ & $(3.64)$ & $(3.49)$ \\
DECK & 0.121 & 0.122 & 0.129 \\
& $(2.95)$ & $(2.97)$ & $(3.08)$ \\
CRTYD & 0.15 & 0.156 & 0.159 \\
& $(4.29)$ & $(4.31)$ & $(4.42)$ \\
SPRINKLER & 0.168 & 0.169 & 0.17 \\
& $(2.54)$ & $(2.57)$ & $(2.66)$ \\
STORIES & 0.16 & 0.161 & 0.157 \\
& $(2.90)$ & $(2.91)$ & $(2.93)$ \\
STUCCO & 0.306 & 0.307 & 0.31 \\
& $(4.55)$ & $(4.79)$ & $(4.80)$ \\
GARAGESP & 0.114 & 0.115 & 0.116 \\
& $(3.45)$ & $(3.50)$ & $(3.54)$ \\
POOLTUB & 0.149 & 0.15 & 0.139 \\
& $(1.99)$ & $(2.01)$ & $(1.74)$ \\
NEW & 0.27 & 0.279 & 0.277 \\
& $(3.68)$ & $(3.70)$ & $(3.62)$ \\
PARKSQ & 0.127 & 0.128 & 0.121 \\
& $(1.98)$ & $(1.99)$ & $(1.98)$ \\
CORNER & 0.031 & - & 0.052 \\
& $(0.33)$ & - & $(0.50)$ \\
CUL & 0.082 & 0.083 & 0.084 \\
LAKERIV & $(2.45)$ & $(2.70)$ & $(2.69)$ \\
& 0.122 & 0.124 & 0.111 \\
APCOMP & $(2.80)$ & $(2.89)$ & $(2.88)$ \\
& -0.042 & -0.043 & -0.042 \\
BUSYST & $(-1.99)$ & $(-2.00)$ & $(-2.03)$ \\
& -0.057 & -0.058 & -0.045 \\
& $(-2.20)$ & $(-2.21)$ & $(-2.25)$ \\
\hline
\end{tabular}

(C) Southern Regional Science Association 2010. 


\begin{tabular}{lrrr}
\hline MAY & 0.141 & 0.152 & 0.151 \\
& $(2.77)$ & $(2.82)$ & $(2.80)$ \\
JUNE & 0.049 & - & 0.032 \\
& $(0.46)$ & - & $(0.40)$ \\
JULY & 0.130 & 0.131 & 0.118 \\
& $(2.06)$ & $(2.07)$ & $(1.79)$ \\
HISTDES & 0.015 & 0.016 & 0.014 \\
& $(1.98)$ & $(1.99)$ & $(1.98)$ \\
DISTRICT & 0.180 & 0.181 & 0.175 \\
& $(2.89)$ & $(2.92)$ & $(2.74)$ \\
$R^{2}$ & & & \\
Adjusted $R^{2}$ & 0.86 & 0.86 & 0.88 \\
$F$ & 0.84 & 0.84 & 0.87 \\
\hline \hline
\end{tabular}

Note: $t$-statistics in parentheses below the respective parameter values.

implies that location in the Savannah Historic Landmark District per se increases a house's sales price. Finally, the natural log of the real sales price is an increasing function of a closing date in either MAY or JULY, implying that it was appropriate to control for these seasonal factors. Thus, of the variables tested, only JUNE and CORNER appear to have no effect.

In Model (b) in Table 3, the basic model is re-estimated but with CORNER and JUNE dropped to test if they might be in any way correlated with the body of other independent variables. The remaining parameter estimates are extremely robust to the change in specification. In Model (b), of the 22 coefficients estimated, 16 are now statistically significant at the onepercent level while 6 are statistically significant at the five percent level. Indeed, in most cases, the coefficients and $t$-values in Model (b) are essentially indistinguishable from those shown for Model (a).

Finally, in Model (c) of Table 3, Model (a) is re-estimated with the variable SQFT replaced by its natural $\log$ form, $\ln (S Q F T)$, following Netusil (2005), who suggests this form is easier to interpret. Overall, the results in Model (c) are quite similar to those for Model (a). The estimated coefficient on the new square footage measure is positive and significant at the onepercent level. Interestingly, this alternative specification yields a higher adjusted $R^{2}$, as well as a higher $F$ statistic, suggesting that it is a more appropriate functional form than that in Model (a). ${ }^{2}$ Otherwise, the only potentially noteworthy differences between the results from Model (a) and (c) are that two variables found to be significant at the five percent level in estimate (a) are now significant at roughly the 7.5 percent level in Model (c)—JULY and POOLTUB, which suggests that these factors may not necessarily play a major role in housing price determination, at least not in Savannah.

A number of other observations merit some discussion. First, with the exceptions of variables CORNER and JUNE, effectively all of the estimated coefficients have the expected

\footnotetext{
${ }^{2}$ Interestingly, the replacement of the square footage variable with a quadratic form for square footage results in a statistically insignificant coefficient for this variable. In addition, the $R^{2}$ falls from 0.84 to 0.81 , the adjusted $R^{2}$ falls from 0.83 to 0.80 , and the value of the $F$ test for the estimate falls from 51.13 to 47.11 .
} 
signs and are statistically significant across estimates. Equally interesting, if not more so, is the relative consistency of the coefficients across estimates. That is, in almost all cases, the coefficient on each of the core statistically significant variables (this distinguishes all other variables from the seasonal controls- $-M A Y$, JUNE, and JULY) exhibits very little variation from one model to the next. Finally, because of these circumstances, it is with a high degree of confidence that we can endeavor to describe the approximate contribution of each of these explanatory variables to the real sales price (in natural log form) of houses in the city of Savannah.

As for the specific contributions of the statistically significant variables on $\ln (R S A L E S P R), 22$ effects can be summarized. In a translog functional form with the dependent variable being expressed in natural log terms, a one-unit change in a non-binary independent variable is interpreted as a percentage effect on the dependent variable that is given by one hundred percent multiplied by the estimated coefficient, ceteris paribus. For example, with respect to the interior features of house $j$, the presence of an additional full or half bathroom tends to cause the real sales price of properties to increase by 10.5 percent. This particular interior property attribute generates the largest positive sales price response. By comparison, the presence of an additional bedroom yields a positive housing price response of roughly 9 percent. This is followed by a more modest price increase provided by a fireplace-roughly 6 percent. The effect of the SQFT variable on the real sales price of house $j$ is handled somewhat differently because the scale of measurement is per square foot rather than per unit. In particular, the mean square footage is 1,789 . A one standard deviation increase in the square footage $(1,280)$ from the mean implies (based on the average of the SQFT coefficients from the first two estimates) a 21.1 percent increase in the real sales price of a typical home in Savannah. This translates into a situation in which, on average, the real housing price rises by roughly \$29.50 (in 2005 dollars) for each additional square foot of finished living space, which lies roughly in the middle of the range for other recent similar studies (e.g., Coulson and Leichenko, 2001; Bin and Polasky, 2004). ${ }^{3}$

Regarding the response of the $\ln (R S A L E S P R)$ to exterior features, we focus first on the number of stories and the number of garage spaces on the premises. Based on the average of the results in Table 3, one additional story yields, on average, a sales price that is about 16 percent higher, and one additional garage space yields about an 11.5 percent price premium.

In interpreting the coefficients on the dummy (binary) variables, we follow the procedure in Halvorsen and Palmquist (1980). To begin, the cladding type appears to exercise a large effect on average. For example, holding other things constant, a house with a brick exterior commands a roughly 24 percent higher sales price than one without a brick exterior, whereas a house with a stucco exterior commands a roughly 34-35 percent higher sales price than one without. The alternatives to brick siding include stucco, as well as wood and aluminum siding. Other things held constant, a house with a private courtyard commands approximately a 17 percent higher sales price than a house without one, whereas a house with an underground sprinkler system commands nearly a 19 percent higher price. Furthermore, other things held constant, a house with a deck commands a nearly 14 percent higher sales price, whereas a house with its own pool and/or hot-tub commands about a 17 percent higher sales price. It is worth observing that the results for each of the last three variables considered-namely, courtyard, underground sprinkler

${ }^{3}$ Based on the result for the $\ln (S Q F T)$ in Model (c), a 10 percent increase in the square footage of a house, on average, would raise its real price 4.82 percent.

(C) Southern Regional Science Association 2010. 
system, and deck-might seem a bit high. Logically, they might be highly correlated with lot size, which is unavailable for most properties in the District, and in many other houses in the study as well, and hence has been omitted as a variable in this analysis. As for the property sales price response to other non-interior and non-exterior features, it appears (other things held the same) that if a house was recently built, it sells with a premium of nearly 31 percent as compared to otherwise similar, existing (not-new) houses.

Next, consider the results for the spatial control variables. A property located across from or adjacent to a park or square commands approximately a 14 percent higher price than a property that is not so situated, whereas location on a corner has no significant property price impact. On the other hand, location on a cul-de-sac results in a housing price premium in excess of 9 percent, while location on a lake or river yields a price premium of roughly 14 percent. Finally, location within two blocks of an apartment complex reduces the price of a house by 5 percent, whereas location on a "busy" street reduces the price of a house by 7 percent.

Moreover, other things held constant, a property that closes during the primary selling season month of May roughly receives a 16 percent price premium compared to a property closed in any month other than July, whereas a house that closed in July obtains around a 14-15 percent price premium. Clearly, housing demand in the City of Savannah peaks during this season, creating a sellers' market and forcing homebuyers to pay a sizeable premium.

Finally, it appears (other things held the same) that a property designated as a national historical landmark (HISTDES) secures about a 1.7 percent premium over a nondesignated property. This premium is distinct from the premium properties derive from their location in the Savannah Historic Landmark District (DISTRICT). Indeed, single-family properties located in the Savannah Historic Landmark District command a real price premium of about 20-21 percent (on average) over otherwise similar properties not located in the District. These results for the case of Savannah are effectively compatible in principle (if not in magnitude) with studies such as Clark and Herrin (1997), Leichenko, Coulson, and Listokin (2001), Coulson and Leichenko (2001), and Coulson and Lahr (2005).

For example, Clark and Herrin (1997, p. 42) find, for the case of the Sacramento housing market, that historic designation “...exerts a net positive influence on housing prices.” They revealed a 10 to 17 percent property price premium from historic designation in most sections of the city. Leichenko, Coulson, and Listokin (2001, p. 1983) find for the City of San Antonio that "historic designation is associated with an 18.6 percent increase in housing values," and in Dallas that there was a " 4.9 percent increase in value associated with historic designation." Thus, in the case of Savannah, it appears that the Savannah Historic Landmark District per se yields a higher housing price premium than do similar districts in Sacramento and selected Texas cities. The results of the present study of single-family residences contrast somewhat, however, with those in the analysis of historical designation for small apartment buildings by Asabere, Huffman, and Mehdian (1994, p. 232), who found "that local historic designation...can produce adverse effects on investment property values." Results from the APCOMP variable do suggest that apartment buildings adversely affect property values, even in historic districts.

\section{CONCLUSION}

This study applies the hedonic pricing model to single-family properties sold during the six-year period 2000 to 2005 in the City of Savannah and the Savannah Historic Landmark 
District, which is a component thereof. The basic model consists of 24 potential factors (6 being spatial control variables) that could influence real housing prices. Furthermore, the estimated models include seasonal control variables for the sales price of single-family properties closed during each of the prime-selling months in Savannah. Estimates from two trans-log variations to a basic model are presented in this study, which examines 2,888 single-family home sales, 591 of which are located in the District.

The principal findings of this study are that the real sales price of a single-family house in Savannah over the 2000-2005 period was positively affected by: the number of bedrooms, bathrooms, fireplaces, stories in structure, and garage car spaces; square footage of finished living space; the presence of a deck, a private courtyard, a pool and/or hot-tub, or an underground sprinkler system; an exterior construction of brick or stucco; and whether the house was new, located across from or adjacent to a park or square, on a cul-de-sac, or on a lake or river. The price of a single-family property in Savannah was also found to be negatively impacted by close proximity to an apartment complex or location on a busy street. The price of a single-family property in Savannah was enhanced modestly by designation as a historic national landmark. In addition, a significant premium (20-21 percent) was paid on average for a house located within the Savannah Historic Landmark District. Finally, there is limited evidence that the real sales price of a house in the City of Savannah also tended to be higher if it closed during the peak selling months of May and July. Thus, there may well be seasonal demand and supply factors that influence Savannah housing prices.

\section{REFERENCES}

Asabere, Paul K. and Forrest E. Huffman. (1994) "Historic Designation and Residential Market Values,” Appraisal Journal, 62, 396-401.

Asabere, Paul K., Forrest E. Huffman, and Seyed Mehdian. (1994) "The Adverse Impacts of Local Historic Designation: The Case of Small Apartment Buildings in Philadelphia," Journal of Real Estate Finance and Economics, 8, 225-234.

Bin, Okmyung and Stephen Polasky. (2004) "Effects of Flood Hazards on Property Values: Evidence before and after Hurricane Floyd," Land Economics, 80, 490-500.

Boyle, Melissa A. and Katherine A. Kiel. (2001) "A Survey of House Price Hedonic Studies of the Impact of Environmental Externalities," Journal of Real Estate Literature, 9, 117144.

Clark, David E. and William E. Herrin. (1997) "Historical Preservation Districts and Home Sales: Evidence from the Sacramento Housing Market,” Review of Regional Studies, 27, 29-48.

Coffin, Donald A. (1989) “The Impact of Historic Districts on Residential Property Values,” Eastern Economic Journal, 15, 221-228.

Coulson, N. Edward and Michael L. Lahr. (2005) "Gracing the Land of Elvis and Beale Street: Historic Designation and Property Values in Memphis,” Real Estate Economics, 33, 487507.

Coulson, N. Edward and Robin M. Leichenko. (2001) "The Internal and External Impact of Historical Designation on Property Values,” Journal of Real Estate Finance and Economics, 23, 113-124. 
Decker, Christopher S., Donald A. Nielsen, and Roger P. Sindt. (2005) "Is Pollution a Homogeneous Determinant of Value?,” Appraisal Journal, 73, 183-196.

Dotzour, Mark G. (1997) “Groundwater Contamination and Residential Property Values," Appraisal Journal, 65, 279-287.

Dubin, Robin. (1998). “Predicting House Prices Using Multiple Listings Data,” Journal of Real Estate Finance and Economics, 17, 35-60.

Ford, Deborah A. (1989) "The Effect of Historic District Designation on Single-Family Home Prices,” AREUEA Journal, 17, 353-362.

Garrod, Guy and Kenneth G. Willis. (1992) "The Environmental Economic Impact of Woodland: A Two State Hedonic Price Model of the Amenity Value of Forestry in Britain,” Applied Economics, 24, 715-728.

Graves, Phillip, John Murdoch, and Mark Thayer. (1988) “The Robustness of Hedonic Price Estimation: Urban Air Quality,” Land Economics, 64, 221-233.

Halvorsen, Robert and Raymond Palmquist. (1980) "The Interpretation of Dummy Variables in Semilogarithmic Equations,” American Economic Review, 70, 474-475.

Harrison, David M., Gregory T. Smersh, and Arthur L. Schwartz. (2001) "Environmental Determinants of Housing Prices: The Impact of Flood Zone Status," Journal of Real Estate Research, 21, 3-20.

Laurice, Jennifer and Radha Bhattacharya. (2005) "Prediction Performance of a Hedonic Pricing Model for Housing,” Appraisal Journal, 73, 198-209.

Leichenko, Robin M., N. Edward Coulson, and David Listokin. (2001) "Historic Preservation and Residential Property Values: An Analysis of Texas Cities,” Urban Studies, 38, 173187.

Levesque, Terrence J. (1994) “Modeling the Effects of Airport Noise on Residential Housing Markets,” Journal of Transport Economics and Policy, 28, 199-210.

McMillen, Daniel P., Paul T. Seaman, and Larry D. Singell. (2007) “A Mismatch Made in Heaven: A Hedonic Analysis of Overeducation and Undereducation," Southern Economic Journal, 73, 901-930.

Murdoch, John, Harold Singh, and Mark Thayer. (1993. "The Impact of Natural Hazards on Housing Values: The Loma Prieta Earthquake,” American Real Estate and Urban Economics Association Journal, 21, 167-184.

Neill, Helen R., David M. Hassenzahl, and Djeto D. Assane. (2007) "Estimating the Effect of Air Quality: Spatial versus Traditional Hedonic Price Models,” Southern Economic Journal, 73, 1088-1111.

Netusil, Noelwah R. (2005) “The Effect of Environmental Zoning and Amenities on Property Values: Portland, Oregon,” Land Economics, 81, 227-246.

Palmquist, Raymond. (1989 "Land as a Differentiated Factor of Production: A Hedonic Model and Its Implications for Welfare Measurement," Land Economics, 65, 23-28.

Sirmans, Stacy, David A. Macpherson, and Emily N. Zeitz. (2005) "The Composition of Hedonic Pricing Models,” Journal of Real Estate Literature, 13, 3-43.

Smith, V. Kerry and Ju C. Huang. (1993) "Hedonic Models and Air Pollution: Twenty-five Years and Counting,” Environmental and Resource Economics, 3, 381-394. 
U.S. Advisory Panel on Historic Preservation. (1979) The Contribution of Historic Preservation on Urban Revitalization. U.S. Government Printing Office: Washington, DC.

U.S. Census Bureau. (2007) Statistical Abstract of the United States, 2007. U.S. Government Printing Office: Washington, DC.

White, Halbert. (1980) “A Heteroskedasticity-Consistent Covariance Matrix Estimator and a Direct test for Heteroskedasticity,” Econometrica, 48, 817-838. 